\title{
A PRELIMINARY STUDY OF LEARNING PLANS IN SPADA LMS BASED ON ASSURE MODEL
}

\author{
${ }^{1,2}$ Tutut Nani Prihatmi, ${ }^{1}$ Maria Istiqoma, ${ }^{1}$ Rini Anjarwati \\ ${ }^{1}$ Faculty of Industrial Technology, National Institute of Technology Malang, Indonesia \\ ${ }^{2}$ Corresponding author email: tutut.nani@ lecturer.itn.ac.id
}

\begin{tabular}{|c|c|}
\hline Article Info & Abstract \\
\hline $\begin{array}{l}\text { Article History } \\
\text { Received: September } 2021 \\
\text { Revised: October } 2021 \\
\text { Published: October } 2021\end{array}$ & $\begin{array}{l}\text { This research aims to investigate how Architecture department's lecturers plan } \\
\text { their courses through SPADA LMS from the perspective of ASSURE model. The } \\
\text { change from face-to-face conventional learning to online requires more } \\
\text { consideration and preparation, especially in learning planning. The ASSURE }\end{array}$ \\
\hline $\begin{array}{l}\text { Keywords } \\
\text { Learning plan; } \\
\text { ASSURE model; } \\
\text { SPADA; }\end{array}$ & $\begin{array}{l}\text { model is one of the instructions and learning plans that can be adopted in } \\
\text { planning, identifying, determining goals, choosing media and material methods, } \\
\text { and evaluating the course. The data collection technique was carried out by } \\
\text { processing and analyzing documents from the literature, interview results, and } \\
\text { questionnaires answered by respondents via links distributed to lecturers of the } \\
\text { Architecture Department, Faculty of Civil Engineering and Planning, National } \\
\text { Institute of Technology Malang. The results show that the six components of the } \\
\text { ASSURE model of the learning planning uploaded in SPADA LMS had not been } \\
\text { implemented optimally. Therefore, the researcher recommends for the } \\
\text { improvement of the Semester Lesson Plan (RPS) based on the ASSURE Model to } \\
\text { promote continuous improvements. }\end{array}$ \\
\hline
\end{tabular}

How to cite: Prihatmi, T. N., Istiqoma, M., \& Anjarwati, R. (2021). A Preliminary Study of Learning Plans in SPADA LMS based on assure model, JOLLT Journal of Languages and Language Teaching, 9(4). pp. 462470. DOI: https://doi.org/10.33394/jollt.v\%vi\%i.4242

\section{INTRODUCTION}

SPADA is a Web-based Learning Management System (LMS) that has become one of the major learning tools utilized at several universities, including the National Institute of Technology (ITN) Malang, as the COVID-19 epidemic necessitates online lectures. SPADA ITN Malang is developed and maintained by the Educational and Instructional Institutions at ITN Malang for carrying out learning activities using IoT facilities. It offers complete features from attendance, books, quiz, forums, surveys, chat, video conference, to sharing materials. SPADA is the main learning platform used at ITN Malang which must be used by all lecturers and students in the learning process. Therefore, the use of SPADA ITN Malang needs to be evaluated from various perspectives, including as a learning plan tool.

Making a learning plan is an important component of a teacher's job since it directly impacts what and how students study the course (Straessle, 2014). Ananda (2019:4) states that planning has four components: (1) Objectives be achieved, (2) Strategies to achieve the goals, (3) the resources to support, and (4) the implementation of each decision. Learning is about how the teacher guide, assist, and direct their students to have a particular learning experience preparing learning experiences for students (Jones in Majid, 2005:16). Therefore, learning plan is a process, scientific discipline, reality, system, and learning technology that aims to help the learning process runs effectively and efficiently (Majid, 2005:18).

For teachers, making a learning plan is of great importance to be able to teach effectively (Hussain et al., 2021) yet also a challenging task (König et al., 2020). It is an organized and sequential process by which teachers make decisions and are required to use 
their professional and educational context knowledge (Blomeke et al., 2015; König et al., 2020; Gallego (2020). Eventually, the ability to understand what and when to employ particular teaching techniques and media will help the teacher to have more proficient classrooms. However, not every teacher attempts to do adequate preparation before to beginning the teaching process, as well as carry out evaluation during or after their class (Prihatmi, 2021). As a matter of fact, most teachers cannot achieve their teaching goals optimally due to ineffective lesson planning and classroom management (Ali, 2020).

There are many learning planning models and approaches that teachers can apply in designing their classrooms. The ASSURE model is one of the instructions and plans which offers to help lecturers on how to plan, identify, determine goals, choose media and material methods, and evaluate (Smaldino, SE, Lowther, DL, \& Russell, 2008). It consists of six stages activities: (1) Analyze learners, (2). State standards and objectives, usually formulated with the ABCD (Audience/learners, Behavior, Condition, and Degree), (3). Select strategies, technology, media and materials, (4). Utilize technology, media, and materials, (5). Require student involvement, and (6). Evaluate and revise so that the learning design can be used effectively and efficiently and for continuous improvement.

The ASSURE model is one of the main references for educators in teaching that has been planned and arranged systematically by integrating technology and media so that learning can run more effectively (Achmadi et al., 2014). It is widely used as the basis for learning planning in middle and high schools and has proven its efficiency in the teachinglearning process. Muammar et al (2015) found that the average grade of SMPN 22 Mataram students taught with ASSURE model is higher than those taught with the conventional model. By having prior knowledge, students have better learning outcomes than students with low prior knowledge. In addition, the application of ASSURE model is proven to promote students' critical thinking skills (Sumliyah et al., 2017; Sari, 2015), and increase student learning motivation ((Achmadi et al., 2014) and students' ability for writing story (Fitriani, 2020).

However, ASSURE model is rarely used in the preparation of learnings in tertiary level. There is no other study to analyze the result of adopting the ASSURE model in a college or university. This present study therefore aims to: (1) investigate how Architecture department's lecturers plan their courses through SPADA LMS from the perspective of ASSURE model, and (2) find out whether this model is suitable to be used as an approach in making learning plans at National Institute of Technology (ITN) Malang. By doing so, this study will be able to serve as the basis for the development research on the next learning plans.

\section{RESEARCH METHOD}

\section{Research Design}

This research is a preliminary study to develop learning plans with the ASSURE Model in the Architecture Department in National Institute of Technology (ITN) Malang in the even semester of 2021/2022. Sujadi (2002) stated that the purpose of Research and Development ( $\mathrm{R}$ and $\mathrm{D}$ ) is to develop a new product or improve an existing product. This research eventually aims to develop the Semester Learning Plan for Architecture Department based on ASSURE model.

\section{Instruments and Participants}

The demography of the respondents in this study were all 18 lecturers of the Architecture Department who taught in the even semester of 2020/2021 academic year. The data collection was competed by analyzing documents from the literature and questionnaires. In this study, a questionnaire was employed to obtain the data. The questionnaire consists of 12 questions with a mix of Closed-Ended Questions with single response "Yes" or "No" and 
Open-Ended Questions with short answers. This questionnaire is in the form of a Google Form containing 10 questions that respondents must answer via a link distributed to all the 18 architecture lecturers.

\section{Data Analysis}

The data collection tool used to generate standardized information from all subjects in the sample of this study was questionnaires as proposed by Borg and Gall (1983). The two types of questionnaires used were closed and opened-ended. The data obtained from the Closed-Ended Questions were in the form of percentage number which showed the rate of 'Dos and Don'ts' (Yes/No), while the data from the Open-Ended Questions were descriptive data which then coded and converted into percentile of each of the respondent. The next step was all respondents were asked to respond to the list of questions prompted in the questionnaires. Having acquired all the responds which were narrated in diverse range of lexicality yet those were telling the same tones, both data were compiled, grouped, and displayed on the basis of the question sections. Such compiling, grouping, and displaying of the questions were aimed to ease the data presentation. The final stage of the data analysis procedure is interpreting the data and generating conclusions (Gunawan, 2013).

\section{RESEARCH FINDINGS AND DISCUSSION Research Findings}

From 18 questionnaires distributed to the Architecture department lecturers, the responses obtained were 10 respondents. $60 \%$ (6 lecturers) are male lecturers, the rest $40 \%$ (4) are female.

Question 1: Are you asked to prepare a Semester Lesson Plan (RPS) before starting your lecture?

All learning activities must begin with the preparation of lesson plans, therefore before starting lectures, lecturers were asked to prepare Semester Learning Plans (RPS). Table 1 shows that $100 \%$ (10) of the respondents/lecturers answered that they were encouraged to prepare and none $(0 \%)$ of the respondents did not prepare lesson plans.

Table 1

Semester Lesson Plan (RPS) Preparation

\begin{tabular}{ll}
\hline Response & Percentage \\
\hline Yes & $100 \%$ \\
\hline No & 0 \\
\hline
\end{tabular}

Question 2: Does your campus set standards in making Semester Lesson Plan?

From Table 2, it is apparently known that there is a standardization in making RPS, which was shown by the $100 \%$ of respondents answered "yes".

Table 2

Standard in Preparing Semester Lesson Plan (RPS)

\begin{tabular}{ll}
\hline Response & Percentage \\
\hline Yes & $100 \%$ \\
\hline No & 0 \\
\hline
\end{tabular}

Question 3: Is there a special template for online Semester Lesson Plan that you prepared?

As a continuation of the previous questionnaire questions about the existence of standardization in the preparation of lesson plans (RPS), then of course there is a special template that is used as a reference. However, from the results of the questionnaire from Table 
3, 90\% of respondents answered yes and the small percentage by ten percent accounted for the absence of the online RPS preparation. It was due to the fact that the teaching and learning was done online, there were still some lecturers who had not prepared RPS online. To some extent online teaching requires a lot of adjustments, therefore some lecturers were still struggling in the sense of finding the appropriate pattern for their course.

Table 3

Template for the Semester Lesson Plan (RPS)

\begin{tabular}{ll}
\hline Response & Percentage \\
\hline Yes & $90 \%$ \\
\hline No & $10 \%$ \\
\hline
\end{tabular}

Question 4: Before starting online lectures, do you analyze the characteristics of the students you will teach, for example (place of residence, time difference, internet network used, student learning styles use laptops, PCs, cellphones, etc.)?

One of the steps before preparing for online learning is the activity of analyzing student characteristics to map some crucial aspects that can affect the teaching and learning process. The mapping can be classified into several categories, namely: 1) residence, 2) internet network, 3) student learning styles when taking online classes. From the data obtained, Table 4 shows that $40 \%$ of lecturers analyzed student characteristics, however 6 lecturers $(60 \%)$ did not do any character analysis. In fact, the number of lecturers not doing such an analysis outweighed the number of lecturers who did the analysis.

Table 4

Analysis of student characteristics

\begin{tabular}{ll}
\hline Response & Percentage \\
\hline Yes & $40 \%$ \\
\hline No & $60 \%$ \\
\hline
\end{tabular}

Question 5: In formulating standards/competencies and learning objectives (setting standards and specific learning objectives) did you use the ABCD (Audience, Behavior/abilities that must be mastered), Conditions that must be mastered, and Degree/learning requirements) model formulation?

ABCD formulation is an ideal help in formulating the Standards or Learning Competencies. From the results of the questionnaire in Table 5, it was found that $70 \%$ of lecturers applied the model, while $30 \%$ did not apply it.

Table 5

ABCD Formulation

\begin{tabular}{|c|c|}
\hline Response & Percentage \\
\hline Yes & $70 \%$ \\
\hline No & $30 \%$ \\
\hline
\end{tabular}

Question 6: State one example of learning competencies contained in your RPS.

From the results of the lecturer's questionnaire, there are four main competencies to be achieved in learning, including cooperative learning competence (competence to be able to work together), cognitive competence (reasoning ability), analytical competence (analytical competence) and oral communication competence (oral communication competence) such as shown in Table 6. 
Table 6

Learning Competency stated in the Semester Lesson Plan

\begin{tabular}{ll}
\hline Respondent & Statement \\
\hline 1 & $\begin{array}{l}\text { Mahasiswa mampu berdiskusi dan bekerja sama dalam membuat konsep } \\
\text { perancangan infrastruktur tapak 1 interior sesuai tema dan konsep interior }\end{array}$ \\
\hline 2 & Mahasiswa mampu membuat dokumen rencana anggaran \\
\hline 3 & Mampu membuat diagram rancangan \\
\hline 5 & Mahasiswa mampu menerapkan unsur dan prinsip perancangan \\
\hline 6 & $\begin{array}{l}\text { Mampu merancang bangunan Mid-Rise Building yang memiliki fungsi campuran } \\
\text { Mengan fokus rancangan pada sistem struktur dan utilitas bangunan }\end{array}$ \\
\hline 7 & Mampu memahami dan menjelaskan instruksi kerja \\
\hline 8 & Mahasiswa dapat mengungkapkan pemikiran secara lisan. \\
\hline 9 & Mahasiswa dapat menyebutkan contoh praktis dari materi ajar \\
\hline 10 & Mahasiswa mampu mengungkapkan pemikiran secara lisan. \\
\hline
\end{tabular}

Question 7: Give an example of choosing strategies, technology, media and materials that will be used to achieve the learning objectives you mentioned in number 6 ?

The selection of strategies, technology, media and materials that are appropriate and in accordance with the character of students in online learning is essential to achieve learning objectives. From Table 7, it can be seen that the lecturer provided several dissimilarity learning tools and strategies in the attempt to achieve their learning objective. Zoom, however, was the main technology-based learning platform used during the learning process.

Table 7

Strategies, Technology, Media, and Materials

\begin{tabular}{ll}
\hline Response & Percentage \\
\hline Zoom meeting & $50 \%$ \\
\hline Study Case & $10 \%$ \\
\hline SPADA & $20 \%$ \\
\hline Videos & $10 \%$ \\
\hline Direct Practice & $10 \%$ \\
\hline
\end{tabular}

Question 8: Have you tested the use of technology, media and teaching materials so that they can function effectively in real learning situations?

Table 8 illustrates that $90 \%$ of lecturers do the test and the other $10 \%$ do not. Seeing the high percentage for testing the teaching platform, most lecturers ensured that the learning platform functions properly so that teaching and learning activities can be carried out with minimal technical constraints.

Table 8

Trial use of technology, media and teaching materials

\begin{tabular}{ll}
\hline Response & Percentage \\
\hline Yes & $90 \%$ \\
\hline No & $10 \%$ \\
\hline
\end{tabular}

Question 9: Is there active participation or involvement of students in the expected materials or competencies in the learning process? Give an example.

In developing the ability and role of students as the center of learning, efforts to involve students in critical thinking processes, exercises and feedback are compelling. Table 9 shows that $70 \%$ of lecturers involved their students yet $30 \%$ did not. While the students' 
participation was in the form of helping select the material/object for the discussion and active cooperative groups.

Table 9

Students' Participation

\begin{tabular}{ll}
\hline Response & Percentage \\
\hline Yes & $70 \%$ \\
\hline No & $30 \%$ \\
\hline
\end{tabular}

Question 10: Do you evaluate the learning design that has been designed?

Evaluation or revising the shortcomings of the projections that have been made from the Semester Lesson Plan function as an effort for continuous improvement. Table 10 displays that $90 \%$ of lecturers did the evaluations at the end of each lesson and only $10 \%$ of them did not do such evaluation. Most of the evaluation process was completed at the end of the learning process in a written or unwritten test.

Table 10

Evaluation

\begin{tabular}{ll}
\hline Response & Percentage \\
\hline Yes & $90 \%$ \\
\hline No & $10 \%$ \\
\hline
\end{tabular}

Question 11: If there is an evaluation, please state the problems/obstacles you got.

The main problem $(60 \%)$ found in Architecture department online learning was the signal quality which was different in each region. Poor internet quality made it difficult for lecturers and students to achieve learning objectives well. The second problem was that the students have difficulty in getting the architectural object for their project as some of them were in remote villages. While product quality and low participation respectively contributed $10 \%$ for the frequent problems encountered during the online teaching and learning.

Table 11

Problems found during the lesson

\begin{tabular}{ll}
\hline Response & Percentage \\
\hline Difficulty in finding learning object & $20 \%$ \\
\hline Internet network & $60 \%$ \\
\hline Product quality & $10 \%$ \\
\hline Low participation & $10 \%$ \\
\hline
\end{tabular}

Question 12: Did you use the evaluation results as a reference in the process of making revisions or improvements to your learning design?

The evaluation stage in the ASSURE model is carried out to assess the effectiveness and practicality of the learning design (Iskandar, 2020). Meanwhile, revision of the learning design is needed to ensure that the learning design can be used effectively and efficiently for continuous improvement. Table 12 shows that $80 \%$ (8) lecturers revised their based on their evaluation, while 1 lecturer stated that revision will be done based on the evaluation result and condition, and 1 lecturer has not done any revision. 
Table 12.

Revision

\begin{tabular}{lc}
\hline Response & Percentage \\
\hline Yes & $80 \%$ \\
\hline No & $0 \%$ \\
\hline Adapted to conditions & $10 \%$ \\
\hline Not Yet Done & $10 \%$ \\
\hline
\end{tabular}

\section{Discussion}

A carefully designed learning plan will be able to ensure the accountability and avoid learning problems that may arise (Friedman, 2021). However, the findings from the data obtained appear to suggest the significances of the research. Firstly, in preparing learning, there have been special appeals and templates from universities which have become standardization in the preparation of RPS, but in the preparation of online learning related to technical, student character analysis, namely distance learning constraints from aspects of domicile, availability and internet networks as well as student learning styles to be able to follow online learning needs to get more attention. The result also illustrated a clearer understanding that planning a design is significantly crucial that most of the respondent undertook the lesson plan in their teaching as it was proposed by (Hussain et al., 2021). Moreover, the fact that some respondents did not do the student's character mapping contradicts the claims of (Smaldino, SE, Lowther, DL, \& Russell, 2008) saying that student character analysis was that of important in the ASSURE model. Some of the respondents or lecturers didn't put such student's character mapping into consideration.

Secondly, the result of the questionnaire shows that some lecturers also have not applied the ABCD model formulation in setting their competency standards. However, it is beyond the scope of this study to confirm the reasons why such formulation was not fully implied. Thirdly, in term of the selection of strategies, technology and media as well as teaching materials in achieving learning objectives has varied and utilizes SPADA LMS but is still not optimal.

Fourthly, concerning the fourth stage of Utilize technology, some lecturers had tested the use of technology, media, and instructional materials to ensure that learning occurs without significant obstacles from either parties, lecturers or students. However, there were still a small number of lecturers who did not conduct trials, which contradicted (Hartini \& Situmorang, 2015) which states that when lecturers deliver teaching materials, they must choose the appropriate method for communicating their knowledge and the material development in the form of multimedia must utilize a program that is simple to use and understand by both students as users and teachers as facilitators.

Fifthly, the role of student involvement in selecting the best material suitable for the learning design was quite high. The students' high level of enthusiasm in getting involved in the learning process was similar to Achmadi et al. (2014) claim stating that the learning strategy which required student participation significantly increased student learning motivation. Lastly, the evaluation of the learning planning design which was one of the core aspects done in the attempt of undergoing revision over the teaching and learning design was carried out by most of the lecturer. The non-revision low figure was grounded for adaptation and existing situational teaching and learning setting. To put into another context, it also meant that constant improvement was still needed to be brought about along with the idea of having the best model which is in the long run effective and efficient to the goal of the learning. Still about the revision of the design, another constraint of applying this learning model was bad signal that contributed the highest in figure. Technical problem was the mono malefactor that couldn't be left untreated. 
From the data discussed above, it can be inferred that there was a gap in the understanding and preparation of e-learning delivered by lecturers via SPADA LMS from the ASSURE model perspective. However, of the 6 criteria proposed by the ASSURE Model, 5 of them received a high positive percentage, those are: State standards and objectives $(70 \%)$, Select strategies, technology, media and materials (100\%), Utilize technology, media, and materials (90\%), Require student involvement (70\%), and evaluate and revise (90\%). This positive percentage rate indicates that the ASSURE Model is has a high possibility to be applied as the main learning plan model at the National Institute of Technology (ITN) Malang.

\section{CONCLUSION}

There are various ways to design a learning plan. Finding the best strategies in a particular teaching-learning environment especially in a state of online learning that is full of challenges, required planning, trials, and continuous research. However, the ASSURE model offers to help comprehensively examine all the learning components (Pribadi, 2011). In this preliminary study, checking the Semester Learning Plan (RPS) using the ASSURE model showed that the learning planning was still not done optimally. However, considering the high percentage in 5 out of 6 criteria of ASSURE model, there is a high possibility to adopt the ASSURE model as the primary learning plan approach in Architecture department. Therefore, we recommend improving the design and realization of the RPS by adopting the ASSURE Model in future research to promote the teaching and learning continuous improvements.

\section{ACKNOWLEDGEMENT}

Our acknowledgment is addressed to the Research and Community Engagement (LPPM) of ITN Malang to grant the funding of this research.

\section{REFERENCES}

Achmadi, H, Suharno, \& Suryani, N. (2014). Penerapan Model ASSURE dengan Menggunakan Media Power Point dalam Pembelajaran Bahasa Inggris sebagai Usaha Peningkatan Motivasi dan Prestasi Belajar Siswa Kelas X MAN Sukoharjo TA 2012/2013. Jurnal Teknologi Pendidikan dan Pembelajaran, 2(1), 35-48

Ananda, R. (2019). Perencanaan Pembelajaran. LPPPI.

Ali, A. (2021). Lesson Planning and Proactive Classroom Management Strategies for Teaching English at Tertiary Level in Pakistan. Elsya : Journal of English Language Studies, 3(1), 8-16. https://doi.org/10.31849/elsya.v3i1.5737

Blomeke, S., Paine, L., Houang, R. T., Hsieh, F. J., Schmidt, W. H., Tatto, M. T., Bankov, K., $€$ Cedillo, T., Cogan, L., Han, S. I., Santillan, M., \& Schwille, J. (2008). Future teachers' competence to plan a lesson: First results of a six-country study on the efficiency of teacher education. ZDM, 40(5), 749-762.

Fitriani, W.A.C. (2016). Meningkatkan Kualitas Proses Pembelajaran dan Kemampuan Menulis Cerita dengan Model ASSURE. Jurnal Pendidikan Dasar dan Pembelajaran, 2(01), 110-121, http://doi.org/10.25273/pe.v6i01.300

Friedman, B \& Allen, K. (2001). Learning Plans. Journal of Teaching in Social Work. http://dx.doi.org/10.1300/J067v21n03_10

Gallego, M. Rodríguez (2007). Lesson planning in Primary and Secondary Education.

Gunawan, I. (2013). Metode Penelitian Kualitatif. Jakarta: Bumi Aksara

Hartini, S., \& Situmorang, J. (2015). Pengembangan Bahan Ajar Berbasis Multimedia Dengan Strategi Pembelajaran Kooperatif (Cooperative Learning) Pada Mata Diklat Analisis Mikrobiologi Di Smk. Jurnal Teknologi Informasi \& Komunikasi Dalam 
Pendidikan, 2(2). https://doi.org/10.24114/jtikp.v2i2.3298

Hussain, B, Zulfqar A Javaid M A. (2021). Planning Teaching and Learning: Examining Potential Benefits as Perceived by School Teachers. PAKISTAN SOCIAL SCIENCES REVIEW, 5(2),938-949, http://doi.org/10.35484/pssr.2021(5-II)73

Iskandar, R \& F, Farida. (2020). Implementasi Model ASSURE untuk Mengembangkan Desain Pembelajaran di Sekolah Dasar. Jurnal Basicedu, 4(4), 1052-1065, https://doi.org/10.31004/basicedu.v4i4.468

König, J., Bremerich-Vos. A., Buchholtz, C. \& Glutsch, N. (2020) General pedagogical knowledge, pedagogical adaptivity in written lesson plans, and instructional practice among preservice teachers, Journal of Curriculum Studies, 52:6, 800-822, https://doi.org/10.1080/00220272.2020.1752804

König, J., Krepf, M., Bremerich-Vos, A., \& Buchholtz, C. (2021) Meeting Cognitive Demands of Lesson Planning: Introducing the CODE-PLAN Model to Describe and Analyze Teachers' Planning Competence, The Teacher Educator, 56:4, 466-487, https://doi.org/10.1080/08878730.2021.1938324

Majid, A. (2005). Perencanaan Pembelajaran, Mengembangkan Standar Kompetensi Guru. Remaja Rosdakarya.

Muammar, H., Hardjono, A., \& Gunawan. (2015). Pengaruh Model Pembelajaran Assure dan Pengetahuan Awal terhadap Hasil Belajar IPA-Fisika Siswa Kelas VIII SMPN 22 Mataram. Jurnal Pendidikan Fisika dan Teknologi, I(3), 166-172

Pribadi, B.A. 2011. Model ASSURE untuk Mendesain Pembelajaran Sukses. Jakarta: PT Dian Rakyat.

Prihatmi, T., Istiqoma, M., \& Anjarwati, R. (2021). Assure Model for Teaching Speaking Online: Teacher Self Reflections. Jurnal Ilmiah Langue and Parole, 4(2), 27-33. https://doi.org/10.36057/jilp.v4i2.477

Hartini, S., \& Situmorang, J. (2015). Pengembangan Bahan Ajar Berbasis Multimedia Dengan Strategi Pembelajaran Kooperatif (Cooperative Learning) Pada Mata Diklat Analisis Mikrobiologi Di Smk. Jurnal Teknologi Informasi \& Komunikasi Dalam Pendidikan, 2(2). https://doi.org/10.24114/jtikp.v2i2.3298

Straessle, Jessica Miller Wunderle. (2014). Teachers' perspectives of effective lesson planning: A comparative analysis. Dissertations, Theses, and Masters Projects. Paper 1550154173. https://dx.doi.org/doi:10.25774/w4-8swa-7371 